\title{
The late Middle Devonian fauna of Red Hill I, Nevada, and its paleobiogeographic implications
}

\author{
Hans-Peter Schultze \\ Natural History Museum and Biodiversity Research Center, and Department of Ecology \& Evolutionary Biology, The University of Kansas, \\ Lawrence, Kansas 66045, U.S.A. E-mail: hp1937@ku.edu \\ With contribution by Loren E. Babcock, Department of Geological Sciences, Ohio State University, Columbus, Ohio, U.S.A. \\ E-mail: Babcock.5@OSU.edu
}

Received 15 May 2009

Accepted 3 August 2009

Published 3 August 2010

\section{Key Words}

\author{
Paleozoic \\ Givetian \\ Euramerica \\ faunal province \\ paleoenvironment
}

\begin{abstract}
The fauna of the Middle Devonian Red Hill I locality, Nevada, is unusual in the cooccurrence of a rich fish assemblage with a rich invertebrate one. Sponges are second in abundance of specimens and number of species only to the fishes and occur together with other invertebrates (conodonts, conulariids, dacryoconarid tentaculites, gastropods, bivalves, brachiopods, arthropods, and unidentifiable ammonoids and echinoderms). The invertebrates indicate a marine depositional paleoenvironment. The conodonts indicate a placement within the lower disparalis Zone, late Givetian. The fish assemblage is dominated by the antiarch Asterolepis. All the other fishes, acanthodians, actinopterygians and sarcopterygians, are less common. The closest biogeographic relationship of the fish fauna is with the Middle/Late Devonian fish fauna of the Baltic Region, followed by that of eastern Canada (Miguasha), Scotland and Iran. This distribution corresponds to the Devonian Euramerica faunal province with connection to eastern Gondwana (Iran and Australia). Localities with the same genera as Red Hill I are interpreted as marine with the exception of the Scottish localities. Asterolepis is the most widely distributed vertebrate genus, mostly marine, but it may be able to enter freshwater like Eusthenopteron if one accepts a freshwater depositional paleoenvironment for the Scottish localities.
\end{abstract}

\section{Introduction}

Red Hill I forms the northern end of the Northern Simpson Park Range, northwest of Eureka, Nevada. The Red Hill I locality (lowest part of Red Hill section II in Murphy et al. 1976, Red Hill I of Gregory et al. 1977) lies near the exposed bottom of a sequence of reddish, yellow and greenish gray silty lime mudstones, approximately $80 \mathrm{~m}$ thick, at the base of the southwest flank of Red Hill (NW 1/4, NE 1/4, section 17, T.25N, R.50E on the Horse Creek Valley 15-Minute Quadrangle in Eureka County, Nevada; or $40^{\circ} 03^{\prime} 3^{\prime \prime} \mathrm{N}$ and $116^{\circ} 02^{\prime} 07^{\prime \prime} \mathrm{W}$ at about $2070 \mathrm{~m}$ [approximately $6220 \mathrm{ft}$.] above sea level).

The locality was discovered by Michael Murphy from University of California, Riverside, California, in 1973. The most common fish, Asterolepis, was first described by Murphy et al. (1976). J. T. Gregory and his student J. Reed from University of California, Berkeley, California, continued the excavations in 1974 and 1975, and J. T. Gregory with another Berkeley crew in 1984.
In 1979 J. Reed completed a Ph.D. thesis on Asterolepis that was never published; he did publish on other fish though (Reed 1985, 1986, 1992). A crew from the University of Kansas excavated in the years between 1981 and 1987: in 1983 together with one German volunteer (P. Brühn) and systematically layer by layer (Fig. 1) in 1987 together with two German volunteers (P. Brühn and E. Thomas).

\section{Stratigraphy}

The fish-bearing section starts $3-4.5 \mathrm{~m}$ above an intraformational conglomerate within the Red Hill Beds and about $80 \mathrm{~m}$ below the Devils Gate Limestone. The Red Hill Beds form an $80 \mathrm{~m}$ thick intercalation between the Denay Limestone below and the Devils Gate Limestone above. The Middle/Late Devonian boundary lies within the Red Hill Beds just above the fish beds. The fishes occur in a little over $1.5 \mathrm{~m}$ thick sequence of wellbedded lime mudstones (Fig. 1). Thicker bedded lime- 


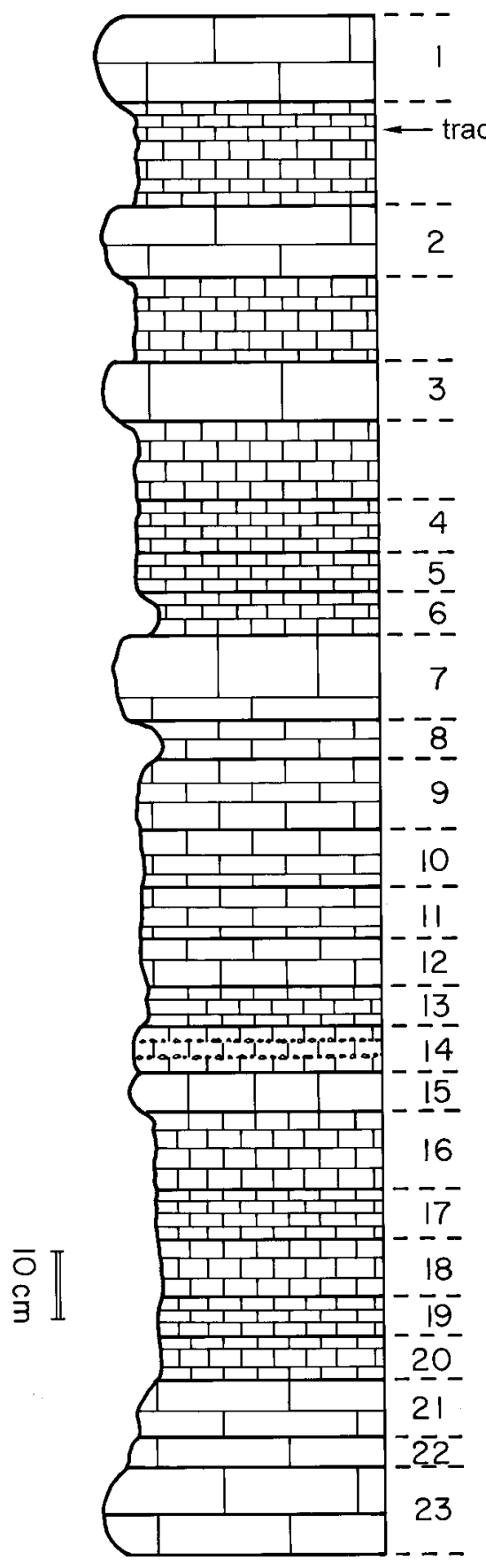

Figure 1. Section of the fish horizons in the thin-bedded lime mudstones alternating with thick-bedded limestones of the Red Hill Beds, Middle Devonian at Red Hill I, Nevada (Middle/Upper Devonian boundary above the section). Symbols from left to right: plants, invertebrates (sponges, conulariids, dacryoconarids, gastropods, bivalves, ammonoids, lingulids, articulate brachiopods, echinoderms) and fishes. stones are intercalated within the finely bedded sequence. Two bone beds occur in layer 14. The layers were numbered from the top down as the excavation progressed. On the right side of the section (Fig. 1), the symbols show the distribution of the fauna. Here we have the unusual situation that a rich fish fauna occurs together with a rich marine invertebrate fauna.

In the literature, different biostratigraphic ages are given for the fish-bearing section, and this has historical reasons. A consensus on the position of the Middle/ Late Devonian boundary was reached in the 1980s. Therefore the placement of the Red Hill I fish beds into the earliest Late Devonian (Johnson 1977: Leiorhynchus hippocastanea Zone [brachiopod interval 25] corresponding to earliest Polygnathus asymmetricus Zone [conodont]) corresponds to the placement of the boundary below the P. asymmetricus Zone. Gregory et al. (1977) and Reed (1985, 1986) supported the early Late Devonian age by comparison with Baltic fish occurrences in the Gauja and Amata beds. With the placement of the Middle/Late Devonian boundary above the earliest $P$. asymmetricus Zone, the fish occurrences were moved into the latest Givetian (Johnson et al. 1988). Murphy et al. (1976) had already given a late Middle Devonian age (upper Schmidtognathus hermanni-Polygnathus cristatus Zone). The conodonts occurring with the fish indicate a placement within the early Klapperina disparalis Zone, latest Givetian (Johnson 
1990, fig. 52; Elliott \& Johnson 1997; Elliott et al. 2000), which corresponds to the present day placement of the Middle/Late Devonian boundary.

Institutional abbreviations. KUMIP - Invertebrate Paleontology collections, and KUVP - Vertebrate Paleontology collections, Natural History Museum \& Biodiversity Research Center, The University of Kansas, Lawrence, Kansas; USNM - U.S. National Museum, Washington D.C., USA.

\section{Fossil assemblage}

The fossil assemblage is unusual among rich fossil fish localities as also being rich in sponges, conulariids, articulate brachiopods, and echinoderms. Plants, gastropods, ammonoids, inarticulate brachiopods and echinoderms are so poorly preserved that they are unidentifiable. Sponges are the most common fossils next to the fishes; the sponge fauna is diverse with 16 different forms. Sponges and conulariids, like most invertebrates and fishes, are flattened; they are preserved, at least in part, with hematite. The change to hematite probably occurred during a widespread hydrothermal event within the region during the Tertiary (Johnson 1960; McKee 1996; Tingley \& LaPointe 1997); that event is responsible for the red color of the sediments. The locality lies within the Battle Mountain - Eureka Trend (French et al. 1996, fig. 3) northeast of the Tonkin Springs mine. Ore deposits and hydrothermal changes of sediments are connected with the intensive fault systems. The age for the hydrothermal event is given as after Miocene basaltic andesites $(16.9 \pm 0.2 \mathrm{Ma})$ for the Buckhorn district (Benedict 1996) northwest of Red Hill I or after the late Oligocene magmatic event (24$25 \mathrm{Ma})$ for the Gold Bar district in the Roberts Mountains (French et al. 1996) southeast of Red Hill I or even earlier (36-38 Ma) after Ressel (2005; Cellura personal comm.).

The co-occurrence of abundant sponges and fishes is most unusual. J. K. Rigby visited the quarry during the 1987 excavation by the Kansas University crew and later described many new sponge genera and species together with D. Mehl (Rigby \& Mehl 1994). The articulate brachiopods were described by Johnson (1978), and the conulariid was described by Babcock \& Feldman (1986a).

\section{Flora and invertebrate fauna of the Red Hill I beds, Nevada}

Plants (letter from P. G. Gensel, Department of Biology, University of North Carolina, Chapel Hill, North Carolina, 14.8.1992):

"pieces of algae resemble charophytes - could be Chara or Nitella" (levels 4-11, 13, 14, 16-20)

Trace fossils (identified by F. Langenstrassen, Institut für Geologie und Paläontologie, Georg-August-Univer- sität, Göttingen, Germany, 18.11.1987):

?Thalassinoides or ?Quebecichnus

"Invertebrates"

Porifera (Rigby \& Mehl 1994):

Hexactinellida

Order Reticulosa

Family Protospongiidae

Actinodictya nevadensis Rigby \& Mehl, 1994 (levels 5, 10, 16)

Actinodictya lamina Rigby \& Mehl, 1994

(levels 10-11, 19)

Protospongia conica Rigby \& Harris, 1979 (level 10)

Family Dictyospongiidae

Cyathophycella minuta Rigby \& Mehl, 1994

(level 21) (Fig. 2)

Cyathophycella grossa Rigby \& Mehl, 1994 (level 16)

Dictyospongia(?) robusta Rigby \& Mehl, 1994 (levels 19-20)

Dictyospongia(?) amplia Rigby \& Mehl, 1994 (level 19)

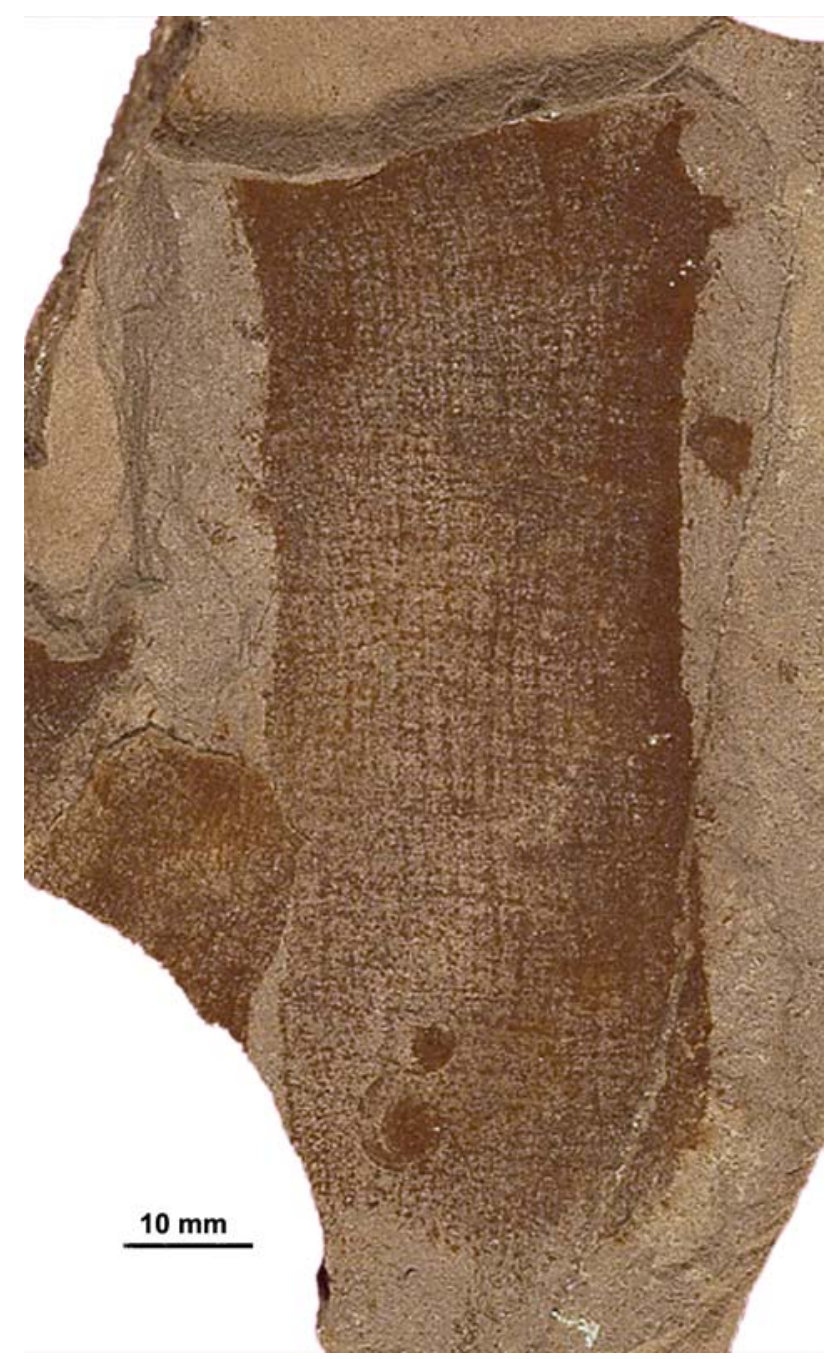

Figure 2. Holotype of the sponge Cyathophycella minuta Rigby \& Mehl, 1994 (USNM 463531, compare Rigby \& Mehl 1994, pl. 4, fig. 11). Lower disparalis Zone, latest Givetian; Red Hill I, northern end of the Northern Simpson Park Range, northwest of Eureka, Nevada. 
Family Hintzespongiidae

Cyathophycus simpsonenis Rigby \& Mehl, 1994 (levels 4, 6-7, 9)

Family Teganiidae

Bulbospongia bullata Rigby \& Mehl, 1994

(levels 16, 18-19, 21)

Rufuspongia triporata Rigby \& Mehl, 1994 (levels 6-8, 11-13)

Rufuspongia sp. (level 19)

Taleolaspongia modesta Rigby \& Mehl, 1994

(levels 2, 7, 12, 18-19, 21)

Teganiella ovata Rigby \& Mehl, 1994

(levels 6-7, 9-11, 17-19)

root tuft A (level 5)

root tuft B (levels 6-8, 10)

root tufts $\mathrm{C}$ (levels $8-9,18$ )

Conulariida (Babcock \& Feldmann 1986a):

Paraconularia recurvatus Babcock \& Feldmann, 1986a (levels 5-7, 9-13, 15-20) (Fig. 3)

Cnidaria:

alveolitid tabulate corals

Dacryoconarida:

(levels 9, 12, 14, 16)

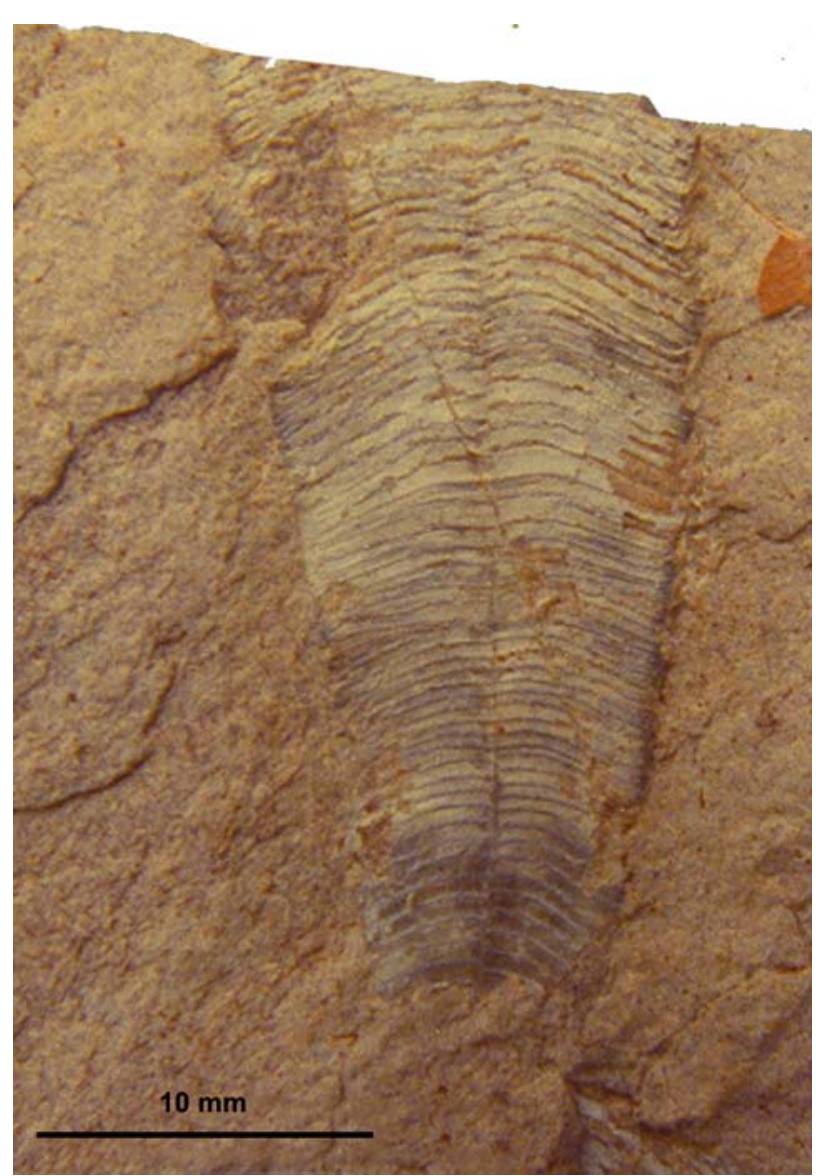

Figure 3. The conulariid Paraconularia recurvatus Babcock \& Feldman, 1986a (KUMIP 314320). Lower disparalis Zone, latest Givetian; Red Hill I, northern end of the Northern Simpson Park Range, northwest of Eureka, Nevada.
Gastropoda:

unidentified (levels 16, 20)

Bivalvia (identified by J. B. Bailey, Dept. of Geology, Western Illinois University, Macomb, Illinois, June 1988):

probable nuculid (level 8)

Buchiola sp. (level 8)

Praecardium sp. A (levels 8-9)

Praecardium sp. B (level 9)

Solemya (?Janeia) sp. (level 9)

Modiella sp. (levels 9, 14)

Ammonoidea (identified by M. S. Peterson, Dept. of Geology, Brigham Young University, Provo, Utah, 27.4.1995):

Unidentifiable specimens [?clymenids]

(levels 6, 9-13, 16-17, 19, 21)

inarticulate Brachiopoda:

unidentified (levels 3-12, 14-19, 21-22)

articulate Brachiopoda (identified by the late J. G. Johnson, Dept. of Geology, Oregon State University, Corvallis, Oregon, 17.12.87: levels 9, 11-12, 14, 16-18; Johnson 1978, 1990):

Leiorhynchus hippocastanea (Crickmay, 1960)

Ladjia russelli (Johnson, 1978)

Vallomyonia claudiae Johnson, 1978

Echinodermata:

unidentifiable stem pieces (levels 6-8, 13-14, 16-21)

Conodonta (identified by M. Murphy, Dept. of Geology, University of California, Riverside, California, 15.10.1992):

Polygnathus cristatus Hinde, 1879 (cited in Murphy et al. 1976)

Klapperina (Palmatolepis) disparilis (Ziegler \& Klapper, 1976 in Ziegler et al. 1976) (cited in Johnson 1978)

Polygnathus foliatus Bryant, 1921 (cited in Gregory et al. 1977)

Polygnathus ordinatus Bryant, 1921 (cited in Gregory et al. 1977)

Schmidtognathus ssp. (cited in Gregory et al. 1977)

Dacryoconarid tentaculites are poorly preserved. Gastropods, bivalves and ammonoids are difficult to identify, and ammonoids cannot be identified even to group, whereas the brachiopods have been used for stratigraphic determination. For echinoderms, only pieces of the stem have been found. Three three-dimensionally preserved specimens of a tabulate coral are kept in the collections of the Museum of Paleontology, Berkeley. The conodonts, like the brachiopods (Leiorhynchus hippocastanea Zone), give an exact age for the deposits. Conulariids and hexactinellid sponges are unusually abundant in the Red Hill I Lagerstätte; they occur in close association with fish throughout most of the quarried section. The sponges are second in number of specimens and species only to the fishes. The co-occurrence of abundant fish and conulariids is known 
otherwise only from one Pennsylvanian locality (Muncie Creek Shale Member of the Iola Limestone, Kansas City Group) in Johnson County, Kansas.

\section{Fish assemblage}

The most common fish in the Red Hill I Lagerstätte (concentration Lagerstätte in the sense of Seilacher 1970) is the antiarch placoderm Asterolepis (Murphy et al. 1976), which occurs disarticulated throughout the section (J. W. Reed described single bones in his Ph.D. thesis 1979). Sometimes complete heads and/or armor, and separate tails of Asterolepis occur; one complete specimen with tail (Fig. 4) has been discovered. Os-

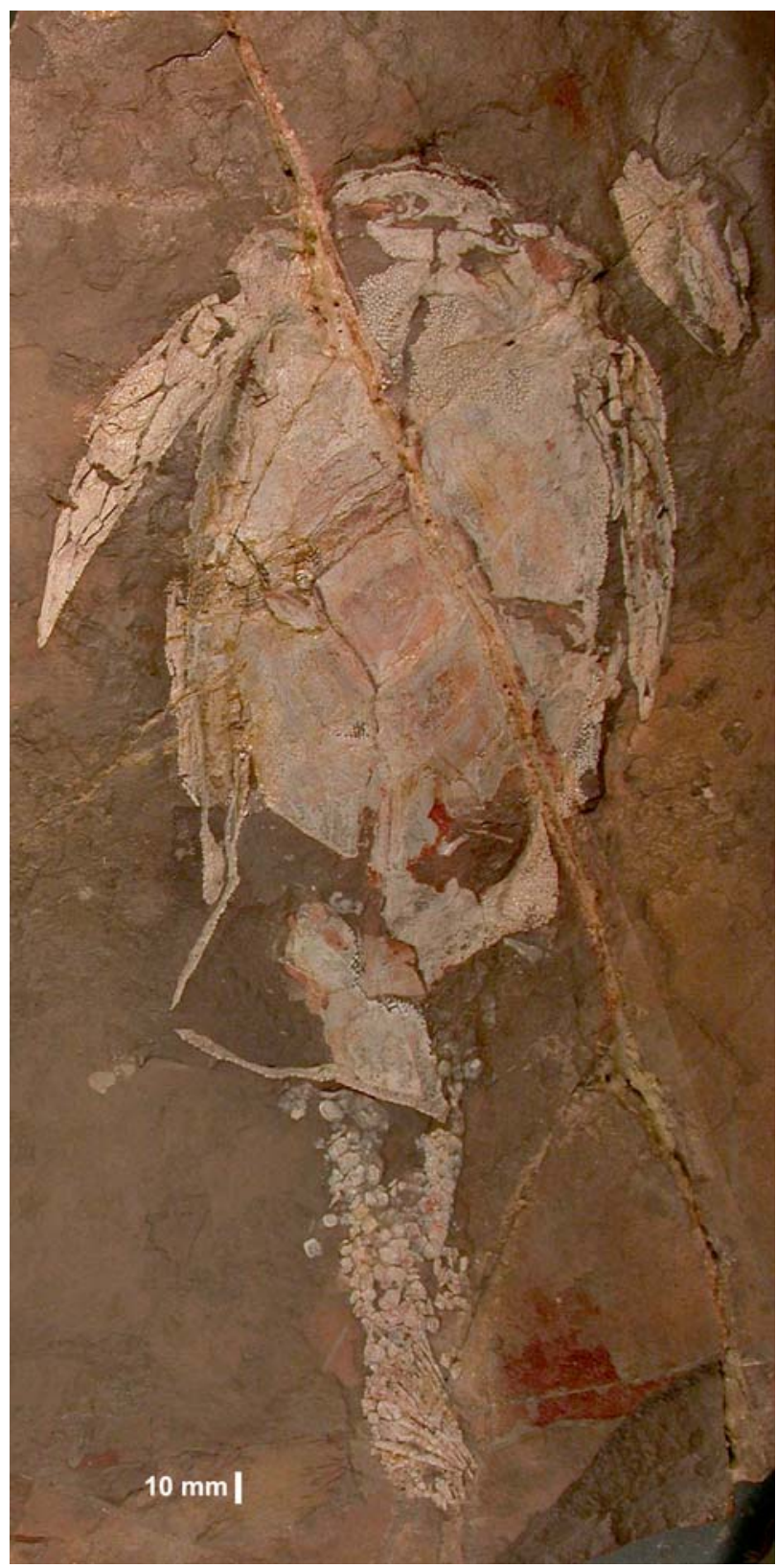

Figure 4. The antiarch placoderm Asterolepis sp. (KUVP 80078A); ventral side. Lower disparalis Zone, latest Givetian; Red Hill I, northern end of the Northern Simpson Park Range, northwest of Eureka, Nevada. teichthyans occur frequently; in descending order of abundance they include lungfish (Reed 1985), rhipidistians and actinopterygians (Reed 1992; Arratia \& Cloutier 2004). Arthrodires, onychodonts, and acanthodians (Reed 1986) are rare.

The Red Hill I fish fauna (Gregory et al. 1977) is diverse. Asterolepis, the most common fish in the Red Hill I Lagerstätte, is the most widely distributed fish genus of the fauna (Schultze \& Cloutier 1996). Upeniece (2002) showed a frequent occurrence of Asterolepis in Givetian to lower Frasnian localities of the Baltic region, NW-Russia, Timan and Scotland. She also listed occurrences in Belgium, Greenland, Spitsbergen, Iran and the eastern USA. In addition, Denison (1978) cited Asterolepis radiata Rohon, 1900 from Kazakhstan and Asterolepis sp. from Australia; Young (1993) added one occurrence from the lower Frasnian of New South Wales, Australia; and Janvier \& Villarroel (2000) described one from Colombia, South America. Such a worldwide distribution indicates a marine form, which is congruent with the interpretation of the depositional environment of most occurrences (Upeniece 2002) except those in Scotland, Greenland, Spitsbergen and New York State, which are interpreted as freshwater deposits by most authors.

\section{Vertebrates}

Placodermi

Asterolepis sp. (levels 3, 5-21): one complete specimen (Fig. 4), heads, trunks, tails, and mainly single plates (Reed 1979)

arthrodire (levels 10-16, 18-19): median dorsal (MD), anterior ventrolateral (AVL), median ventral (MV) plates of coccosteid, suborbital (SO) plate of plourdosteid (Gregory et al. 1977 cite cf. Coccosteus and cf. Plourdosteus) and anterolateral (AL) plates of pachyosteine arthrodires

Acanthodii

Machaeracanthus sp. (level 20): spines (Reed 1986, fig. 1)

Persacanthus simpsonensis Reed, 1986

(levels 10, 14, 17): jaws (Reed 1986, figs 2-6)

Actinopterygii

Cheirolepis schultzei Arratia \& Cloutier, 2004

(levels 7-9, 11-12, 14-16, 18-20): anterior body (Arratia \& Cloutier 2004, figs 2-4, 5A, 6-8), scales and isolated elements (Reed 1992, figs 12; Arratia \& Cloutier 2004, figs 1, 9-10).

rhombic palaeoniscoid scales

(levels 6, 8-12, 14-19, 21)

Sarcopterygii

Onychodontida (levels 9, 11, 15-16, 18) teeth and tooth spirals

Dipnoi

Griphognathus sp.: lower jaw (Reed 1985, figs 3-4) 


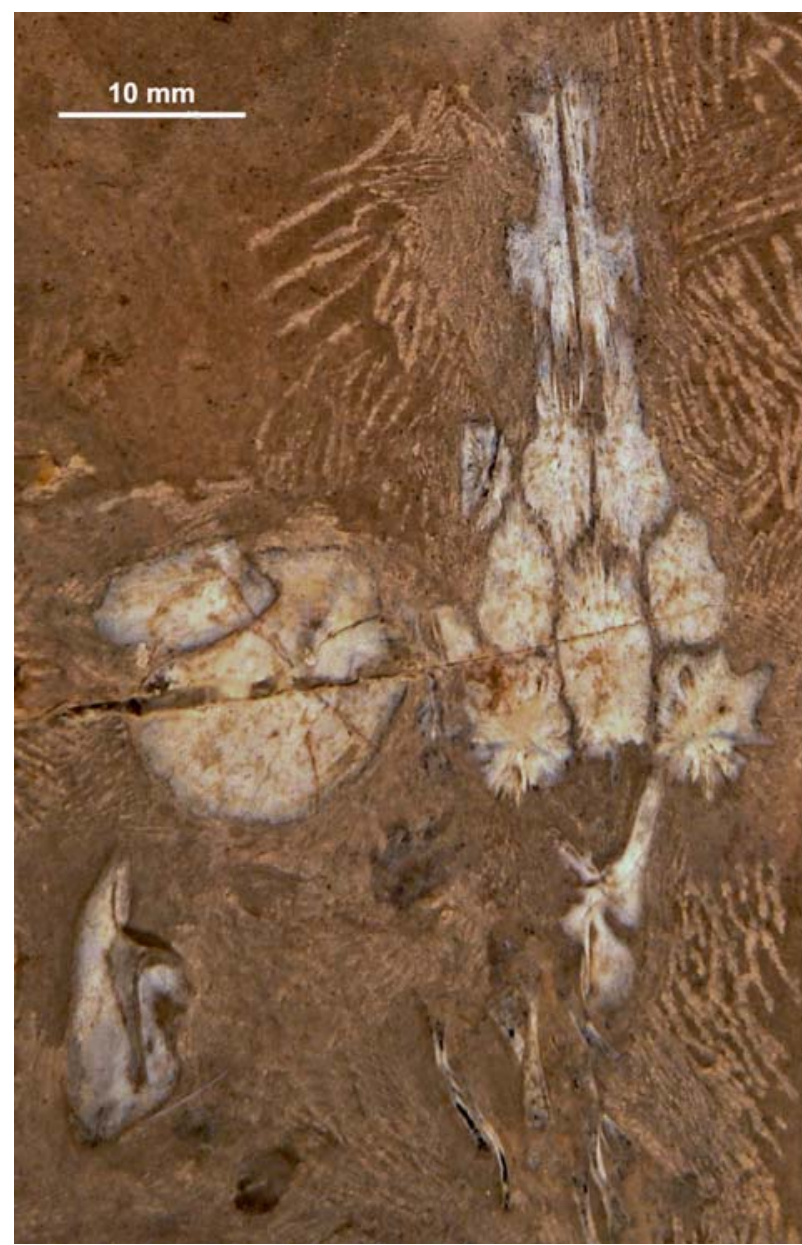

Figure 5. The dipnoan Soederberghia sp. (KUVP 93035); skull roof under alcohol. Lower disparalis Zone, latest Givetian; Red Hill I, northern end of the Northern Simpson Park Range, northwest of Eureka, Nevada.
Soederberghia sp.: skull roof (Fig. 5)

dipterid indet. (levels 8-9, 16, 18): tooth plates (Reed 1985, figs 5-7), skull roof bones

dipnoi indet. (levels $6,8,10-13,16-19$ ): single elements (Reed 1985, figs 1-2, 8-9), nearly complete specimens

Rhipidistia

tristichopterid n. gen. n. sp. (levels 13, 17-18): head (Fig. 6)

osteolepid indet. (levels 6, 8-21): complete specimens

The new tristichopterid (Fig. 6) is quite closely related to Eusthenopteron, if it is placed in the phylogenetic diagram of Ahlberg \& Johanson (1997). Shape of lacrimal and jugal, presence of only one supraorbital and the longest preorbital region compared to the skull roof length of all tristichopterids are unique features of the new form. The new tristichopterid has enlarged premaxillary and anterior dentary fangs, a feature typical for advanced (above Eusthenopteron) tristichopterids (manuscript in preparation).

\section{Taphonomy}

Besides the rare co-occurrence of abundant fish and conulariids, the co-occurrence of abundant fish and glass sponges is exceptional (Rigby \& Mehl 1994; e.g. beds 10-12). Fishes, conulariids, and sponges show similar preservation in the Red Hill I Lagerstätte. All have been flattened; it is unusual that all conulariids from a locality are crushed to this extent. Crushing in some conulariid specimens evidently occurred follow-

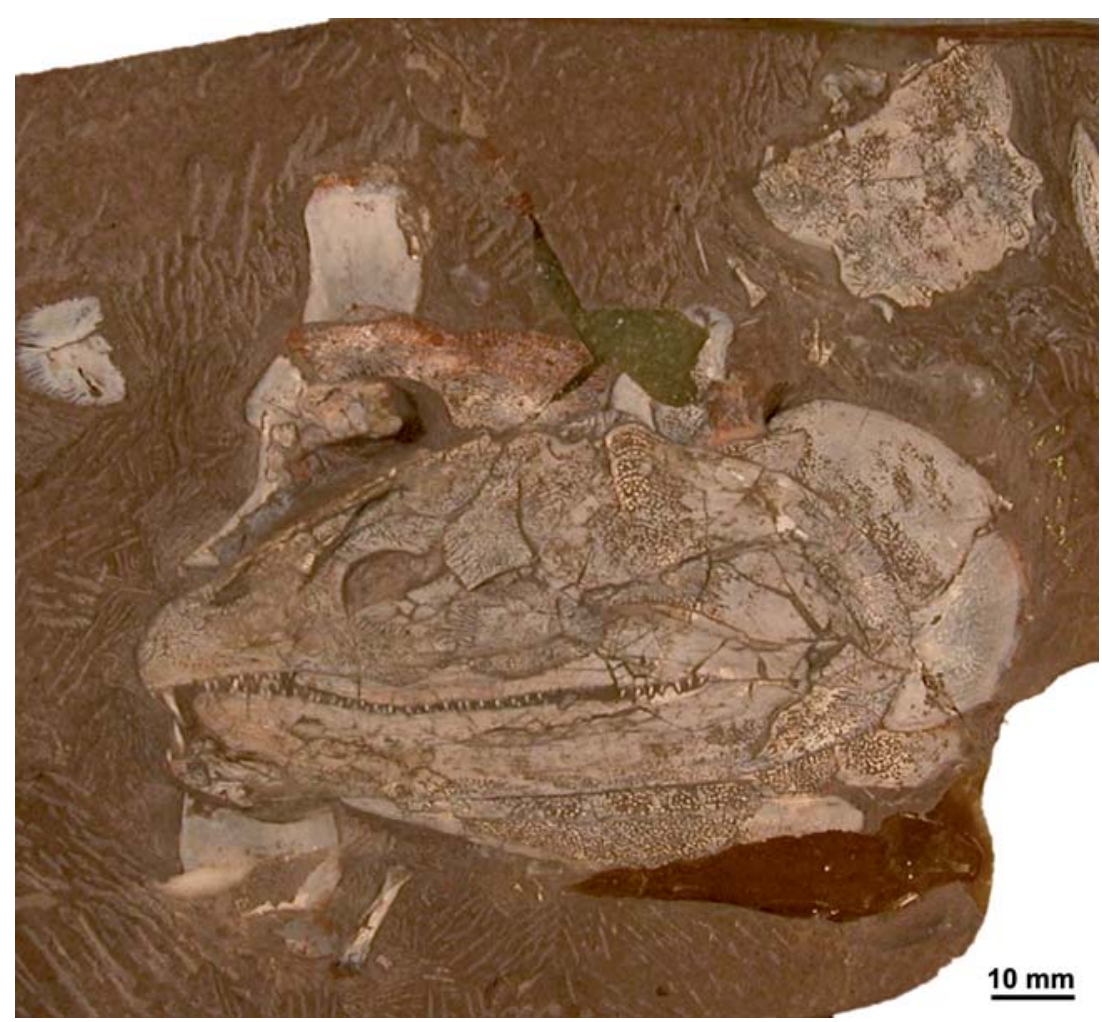

Figure 6. The tristichopterid rhipidistian n. gen. n. sp. (KUVP 94040); head in left lateral view under alcohol. Lower disparalis Zone, latest Givetian; Red Hill I, northern end of the Northern Simpson Park Range, northwest of Eureka, Nevada. 
ing initial exoskeletal collapse because some specimens show older, postmortem infolding of the relatively weak exoskeleton in the apertural region. These taphonomically produced structures have been called apertural lappets in the earlier literature (Babcock 1993; Babcock et al. 1987).

Fishes, sponges and conulariids are preserved in various states of disarticulation. Isolated parts of fishes are most common, but sometimes nearly complete specimens can be found (Fig. 4). In addition, fish bone beds have been found in level 14. The sponges are generally fragmented (Rigby \& Mehl 1994). However, the presence of complete specimens (Fig. 2) and the presence of seemingly undisturbed thin bedding, together suggests that benthic scavengers and sediment bioturbators are largely excluded from that environment. Rapid and deep burial, dysaerobic conditions, and perhaps hypersaline conditions, are examples of situations that would tend to exclude the scavengers and therefore be conducive to their preservation as fossils. Most conulariids are relatively complete, articulated exoskeletons (Fig. 3) but disarticulated exoskeletal pieces, including individual rods, do occur. The relatively large number of articulated, but not fully complete conulariid exoskeletons contrast with mostly disarticulated specimens of fishes and sponges. The fact that tiny exoskeletal pieces are preserved adjacent to articulated specimens of conulariids and fishes, instead of being washed away, suggests that current agitation and bioturbation of the sediment surface was quite limited except in the bonebeds of level 14. By analogy with the occurrence of disarticulated conulariids in a Mississippian black shale from Ohio (Babcock \& Feldmann 1986b), it is inferred that some Red Hill I conulariids were lying on the sediment surface long enough for some disarticulation to occur without interference by currents, benthic scavengers, or sediment bioturbators. Scavengers of conulariids and fishes as well as burrowing organisms, may have been largely excluded from the site of deposition.

There is no indication of disturbance of the specimens after deposition. Thus one has to conclude that the specimens arrived as pieces (disarticulation through decay while floating) or complete at the depositional site. Marginal disturbance has to be explained by crushing or last forms of decay.

\section{Paleoecology}

The invertebrates indicate a marine depositional paleoenvironment. The presence of conulariids in the Red Hill I fauna yields limited paleoecological information because these animals seem to have been rather ubiquitous in many Paleozoic marine habitats (Babcock \& Feldmann 1986b). Conulariids are known only from marine strata. Paraconularia recurvatus may have been an opportunistic species, as judged by its abundance (conulariids occur usually single or as few specimens), and by the lack of other conulariid species in the fauna. Conulariids as a general rule were evidently capable of tolerating conditions ranging from well-oxygenated to poorly oxygenated (Babcock 1991), and were not restricted by water depth, at least not in shelf seas. Murphy (1977) considered the paleoenvironment of the Northern Simpson Park Range as open marine at the time (also see Rigby \& Mehl 1994); Johnson et al. (1988) placed the sedimentation of the limestones on the outer shelf. The trace fossils, which indicate a near shore paleoenvironment, occur only in one horizon above the section with the fish-sponge-conulariid assemblage (Fig. 1).

According to Denison (1978, p. 108), antiarchs are predominantly freshwater stream and lake dwellers, though a few (Gerdalepis, Lepadolepis and Grossaspis) became adapted to marine life. Asterolepis is common in coastal marine sediments of the Middle and Upper Devonian of the Baltic region (Gauja beds, Burtniecki, Upper Narova, Aruküla, Armata beds) and in sediments interpreted as freshwater deposits of Scotland (Nairn sandstone, Upper Ronsay series and Brindister flags) and Greenland (Tab. 1). Asterolepis juveniles occur in coastal marine waters (Lode, Latvia; Upeniece \& Upenieks 1992), and by comparison with extant (or Pennsylvanian of the North American mid-continent) marine fish behavior (Gunter 1961) this is a further indication that Asterolepis lived in marine environments. The

Table 1. Distribution of some Red Hill I fishes in the Givetian/Frasnian.

\begin{tabular}{|c|c|c|c|c|c|c|c|c|}
\hline Red Hill I & $\begin{array}{l}\text { Eastern } \mathrm{N} \\
\text { America }\end{array}$ & E Greenland & Scotland & $\begin{array}{l}\text { W Central } \\
\text { Europe }\end{array}$ & $\begin{array}{l}\text { Baltic } \\
\text { NW Russia }\end{array}$ & Iran & Australia & S America \\
\hline Asterolepis & $\bullet$ & ○ & $\bigcirc \bigcirc ০$ & $\bullet \bullet$ & $\square \square \square \square$ & $\bullet$ & & $\bullet$ \\
\hline Machaeracanthus & $\bullet \bullet$ & & & & & & & \\
\hline Persacanthus & & & & & & $\bullet$ & & \\
\hline Cheirolepis & $\square$ & & 0 & $\bullet \bullet$ & $\square \square \square$ & & & \\
\hline Griphognathus & & & & $\bullet$ & $\square$ & & $\bullet$ & \\
\hline Soederberghia & 0 & 0 & & & & & 0 & \\
\hline tristichopterids ${ }^{1}$ & $\square$ & & 0 & $\square$ & $\square$ & & ○० & \\
\hline
\end{tabular}

- = marine, $\square$ = shallow marine, $\bigcirc=$ "freshwater", number of symbols $=$ frequency of occurrence, ${ }^{1}=$ see text. 
acanthodians, Machaeracanthus and Persacanthus, and the dipnoan Griphognathus are typical marine fishes (Campbell \& Barwick 1988). The actinopterygian Cheirolepis appears to have been adapted to a marine environment, except for the occurrences in Scotland, which are interpreted as "freshwater" deposits (see Schultze 1999, p. 380). The occurrence of Soederberghia at Red Hill I is the only clear marine occurrence of the genus, even though Ahlberg et al. (2001) suggested the habitat of the genus as non-marine to shallow near-shore marine. The figured tristichopterid (there seem to be two different tristichopterids at Red Hill I) is very similar to Eusthenopteron and has been identified as Eusthenopteron by Reed (1979) and by Elliot \& Johnson (1997) in biostratigraphic comparisons and by Schultze \& Cloutier (1996) in paleoecological comparisons. In Table 1, the Red Hill I tristichopterid is recorded together with other tristichopterids to discuss the paleogeographic distribution of the group (see below).

The fishes at Red Hill I occur in a definitive marine environment as indicated by the invertebrate fauna. There is no indication that the fishes have been washed in; the bone beds are reworked zones closer to shore. Laterally the Red Hill I beds continue in limestones of marine origin. That habitat indicates marine adaptation of these fishes; their occurrences in putative freshwater deposits require an explanation if one accepts the sedimentological interpretations of the Scottish, Greenland and Australian localities. Either different species of these genera had different adaptations, or they could enter freshwater without too much difficulties as some marine fishes can today (in contrast: freshwater fishes except catadromous species cannot enter marine environments).

\section{Comparison with other faunas}

All the sponges (Rigby \& Mehl 1994) despite their diversity are endemic to the Red Hill I Lagerstätte at species and in cases generic level. They are the last (Cyathophycus, Protospongia) or the first (Actinodictya, Teganiella) known occurrences of the genus. Cyathophycella is restricted during its whole temporal occurrences to the Roberts Mountains/Northern Simpson Park Range area of Nevada. Actinodictya is the only genus with species of similar age (Frasnian) in New York State. This connection to the eastern United States is supported by the occurrence of Dictyospongia in the Late Devonian rocks of New York State.

"Only one conulariid species, Paraconularia recurvatus Babcock \& Feldman, 1986a, is represented, and it is endemic to the Red Hill I locality. P. recurvatus is the oldest species of the genus known from North America, and shows a morphology consistent with its inferred phylogenetic position as a form intermediate between Early to Middle Devonian species of Conularia and Mississippian species of Paraconularia. The close spac- ing of rods is characteristic of a species in the presumed ancestral genus Conularia, whereas strongly reduced spines and, to a lesser extent, the recurvature of the rods, is characteristic of Paraconularia species. The only other known Paraconularia from the Devonian of North America are P. chagrinensis Babcock \& Feldmann, 1986a, from the Upper Devonian of Ohio; P. wellsvillia Babcock \& Feldmann, 1986a, from the Upper Devonian rocks of New York; and an undescribed species from the Devonian-Mississippian transition beds of South Dakota (Babcock \& Feldmann 1986a). Worldwide, only two described species of Paraconularia, P. africana (Sharpe, 1856), and P. ulrichana (Clarke, 1913), are older than $P$. recurvatus. Both species are from Lower to Middle Devonian strata of the Malvinokaffric Realm in South America and southern Africa (Babcock 1993; Babcock et al. 1987). The genus Paraconularia has an Euramerican - Gondwanan distribution." (Babcock).

The fishes at Red Hill I show a worldwide distribution on a generic level (Tab. 1) as can be expected from marine fishes. Asterolepis has its widest distribution around the Middle/Late Devonian boundary, as shown by Young $(1981,1993)$ and Janvier \& Villarroel (2000). The distribution of Asterolepis coincides with the occurrences of the widely distributed antiarch Bothriolepis, for which Young (2003) suggested a dispersal through the sea. The acanthodian Machaeracanthus was widely distributed in the Early and early Middle Devonian. The actinopterygian Cheirolepis seems to be limited to the northern continents (Laurentia and Baltica at the time), whereas the dipnoans Griphognathus and Soederberghia, and the tristichopterid rhipidistians were cosmopolitan.

Young (1981, 1993, 2003) based migration pattern mainly on the "freshwater" occurrences of groups (xenacanth sharks, phyllolepid placoderms, large rhizodont crossopterygians and early tetrapod amphibians), which are not present in the Red Hill I fauna. He favors a migration of these groups from eastern Gondwana westwards. In contrast, I favor here marine occurrences of the Red Hill I taxa and like to argue that the marine adaptation of these genera (Tab. 1) gave them the freedom to move between areas. Asterolepis is known from Laurussia and northern Gondwana (South America); records from Australia (Denison 1978) are doubtful. The actinopterygian Cheirolepis is widely distributed in Laurussia, but not recorded from Gondwana. The lungfish Griphognathus is known from Laurussia and Australia from the earliest Frasnian; the Red Hill I occurrence is somewhat older as may be the occurrence in Bergisch Gladbach, Germany. Soederberghia co-occurs with early tetrapods in Australia, North America and Greenland. The occurrence in Red Hill I is the earliest and marine record of the taxon. These early occurrences of the two lungfish in Laurussia and later occurrences in Australia contradict Young's proposed direction of migration. A special group of interest are the tristichopterids. Ahlberg \& Johanson (1997) argued that 
all primitive tristichopterids occur in Laurussia, a migration to Australia is postulated. Young (2008) countered that conclusion with establishing a new subfamily, Mandageriidae, for the advanced Australian tristichopterids. That excludes that endemic group from a migration pattern (Clement et al. 2009 suggested biogeographical barriers). The tristichopterid from Red Hill I is as old as the earliest Australian form and younger than the earliest Eusthenopteron records. In conclusion, it seems that there is no unidirectional migration, but an exchange between Laurussia and Gondwana (Young 2008).

The Red Hill I Lagerstätte was included in the comparison of the Escuminac Formation ichthyofauna with other late Givetian/early Frasnian ichthyofaunas by Schultze \& Cloutier (1996), even though the Red Hill I ichthyofauna was not fully prepared and described at that time. The Red Hill I ichthyofauna appeared close to Russian and Baltic region ichthyofaunas on a generic level, and close to Scottish ichthyofaunas on family level in that analysis. The close connection to European localities is no problem for a marine fauna that could migrate along the continental margins. Red Hill I clusters with marine localities worldwide: Iran, Germany, Australia, northwest Russia, the Baltic region, Antarctica, and France. Gogo, Australia (Campbell \& Barwick 1999), and Bergisch-Gladbach, Germany (Jux 1963; Schultze 1969; Jessen 1993), are marine localities of Griphognathus, and Koknese, Latvia (Gross 1956; Kuršs 1992; Lukševičs 2001), is a near-shore marine locality with Griphognathus. In contrast, the widely distributed localities of Soederberghia are interpreted as non-marine (Ahlberg et al. 2001) with the exception of Red Hill I, Nevada.

Schultze \& Cloutier (1996) evaluated which fishes determined the clusters of localities and which indicated the depositional environments of the localities. The analysis resulted in a big cluster (assemblages II-V) of marine forms including Griphognathus, Persacanthus and a tristichopterid, Eusthenopteron. Asterolepis is part of assemblage I in Schultze \& Cloutier (1996), the most widely distributed assemblage (in 24 of 38 localities). It occurs with other widely distributed genera having a marine preference, but also occurs in environments interpreted as freshwater deposits. Schultze \& Cloutier (1996) concluded that there is no clear "freshwater" assemblage. Lelièvre (2004) reached the same conclusion for the Famennian using a different methodology. The interpretation of these fishes as marine is thus the most plausible one. All the "freshwater" occurrences, if correct, could represent migrations of these fishes into freshwater.

\section{Acknowledgements}

The excavations in 1981 and 1983 were supported by the Division of Vertebrate Paleontology, Museum of Natural History, University of Kansas, the excavation of 1987 was supported by National Geo- graphic grant 3516-87 to Schultze. I am thankful to O. Bonner, former preparator at the Division of Vertebrate Paleontology, the former graduate students J. Chorn, M. Gottfried and J. McAllister and the German helping hands, P. Brühn and E. Thomas, for their hard work in the field. J. B. Bailey, J. G. Johnson, F. Langenstrassen, M. Murphy and M. S. Peterson kindly gave identifications of invertebrates, and P. G. Gensel identified some plants. D. Goujet verified kindly the identifications of arthrodire plates. B. Swartz spent days to help me in the collections of the Museum of Paleontology, Berkeley, and he kindly photographed some specimens. Special thanks go to M. Murphy, who introduced me to the fish localities in the Roberts Mountains and the Northern Simpson Park Range. M. Murphy permitted the use of the facilities of his geology field camp (University of California at Riverside) in the northern Roberts Mountains. The fish fossils were prepared by L. Berner, preparator at the Museum für Naturkunde in Berlin, Germany. The manuscript was written when I was guest in the division of vertebrate paleontology of the Natural History Museum, University of Kansas, Lawrence, KS. Desui Miao kindly corrected the English. Brian Cellular, Miranda Gold Corp., Eureka, Nevada, informed me kindly about alteration/mineralization of deposits in the area; and the geoscience librarian Linda P. Newman at Mackay School of Mines, University of Nevada in Reno located Ressel's thesis even though I had only a wrong name. Anonymous reviewers, J. Clack and J. Long helped to improve the manuscript especially by their requests to support statements by additional citations.

\section{References}

Ahlberg, P. E. \& Johanson, Z. 1997. Second tristichopterid (Sarcopterygii, Osteolepiformes) from the Upper Devonian of Canowindra, New South Wales, Australia, and phylogeny of the Tristichopteridae. - Journal of Vertebrate Paleontology 17 (4): 653-673.

Ahlberg, P. E., Johanson, Z. \& Daeschler, E. B. 2001. The Late Devonian lungfish Soederberghia (Sarcopterygii, Dipnoi) from Australia and North America, and its biogeographical implications. Journal of Vertebrate Paleontology 21 (1): 1-12.

Arratia, G. \& Cloutier, R. 2004. A new cheirolepidid fish from the Middle-Upper Devonian of Red Hill, Nevada, USA. In Arratia, G., Wilson, M. V. H. \& Cloutier, R. (eds). Recent Advances in the Origin and Early Radiation of Vertebrates. Verlag Dr. F. Pfeil, München: pp. 583-598.

Babcock, L. E. 1991. Paleoecologic and taphonomic controls on conulariid distributions: example from Pennsylvanian cyclothems of Kansas and Oklahoma. - Geological Society of America, Abstracts with Program 23 (1): 4.

Babcock, L. E. 1993. Exceptionally preserved conulariids from the Conularienschichten, Fossil-Lagerstätten in the Devonian of Bolivia. In Suárez Soruco, R. (ed.). Fósiles y Facies de Bolivia, Vol. II, Invertebrados y Paleobotanica. - Revista Técnica de Yacimientos Petroliferos Fiscales Bolivianos 13/14 (1-4): 77-91.

Babcock, L. E. \& Feldmann, R. M. 1986a. Devonian and Mississippian conulariids of North America. Part B. Paraconularia, Reticulaconularia, new genus, and organisms rejected from Conulariida. - Annals of the Carnegie Museum 55 (16): 411-479.

Babcock, L. E. \& Feldmann, R. M. 1986b. Devonian and Mississippian conulariids of North America. Part A. General description and Conularia. - Annals of the Carnegie Museum 55 (15): 349410.

Babcock, L. E., Feldmann, R. M., Wilson, M. T. \& Suárez-Riglos, M. 1987. Devonian conulariids of Bolivia. - National Geographic Research 3: 210-231.

Benedict, J. F. 1996. Buckhorn Project, Eureka County, Nevada. In Green, S. M. \& Struhsacker, E. (eds). Geology and Ore Deposits of the American Cordillera. April 10-13, 1995, Reno/Sparks, Nevada. Field Trip Guidebook Compendium, Geological Society of Nevada, Reno, Nevada: pp. 304-308. 
Bryant, W. L. 1921. The Genesee conodonts. - Buffalo Society of Natural Sciences, Bulletin 13 (2): 1-59.

Campbell, K. S. W. \& Barwick, R. E. 1988. Geological and palaeontological information and phylogenetic hypotheses. - Geological Magazine 125 (3): 207-227.

Campbell, K. S. W. \& Barwick, R. E. 1999. Dipnoan fishes from the Late Devonian Gogo Formation of Western Australia. - Records of the Western Australian Museum, Supplement 57: 107-138.

Clarke, J. M. 1913. Fosseis Devonianos do Paraná. - Serviço Geológico y Minería do Brasil, Monografias 1: 1-353.

Clement, G., Snitting, D. \& Ahlberg, P. E. 2009. A new tristichopterid (Sarcopterygii, Tetrapodomorpha) from the upper Famennian Evieux Formation (Upper Devonian) of Belgium. - Palaeontology 52 (4): $823-836$.

Crickmay, C. H. 1960. The older Devonian faunas of the Northwest Territories. Imperial Oil Ltd., Calgary.

Denison, R. 1978. Placodermi. In Schultze, H.-P. (ed.). Handbook of Paleoichthyology. Vol. 2. Gustav Fischer Verlag, Stuttgart, New York: pp. 1-128.

Elliott, D. K. \& Johnson, H. G. 1997. Use of vertebrates to solve biostratigraphic problems: Examples from the Lower and Middle Devonian of western North America. - Geological Society of America, Special Paper 321: 179-188.

Elliott, D. K., Johnson, H. G., Cloutier, R., Carr, R. K. \& Daeschler, E. B. 2000. Middle and Late Devonian vertebrates of the western Old Red Sandstone Continent. - Courier Forschungsinstitut Senckenberg 223: 291-308.

French, G. M., Fenne, F. K., Maus, D. A., Rennebaum, T. D. \& Jennings, T. A. 1996. Geology and Mineralization of the Gold Bar District, Southern Roberts Mountains, Eureka County, Nevada. In Green, S. M. \& Struhsacker, E. (eds). Geology and Ore Deposits of the American Cordillera. April 10-13, 1995, Reno/Sparks, Nevada. Field Trip Guidebook Compendium, Geological Society of Nevada, Reno, Nevada: pp. 309-315.

Gregory, J., Morgan, T. \& Reed, J. 1977. Devonian fishes. In Murphy, M. A., Berry, W. B. N. \& Sandberg, C. A. (eds). Western North America: Devonian. - University of California, Riverside Campus Museum, Contribution 4: 112-121.

Gross, W. 1956. Über Crossopterygier und Dipnoer aus dem baltischen Oberdevon im Zusammenhang einer vergleichenden Untersuchung des Porenkanalsystems paläozoischer Agnathen und Fische. - Kunglika Svenska VetenskapsAkademiens Handlingar (4) 5: 1-140.

Gunter, G. 1961. Some relations of estuarine organisms to salinity. Limnology and Oceanography 6: 182-190.

Hinde, G. J. 1879. On conodonts from the Chazy and Cincinnati Group of the Cambro-Silurian, and from the Hamilton and Genesee-Shale division of the Devonian, in Canada and the United States. - Quarterly Journal of the Geological Society, London 35: 351-369.

Janvier, P. \& Villarroel, C. 2000. Devonian vertebrates from Colombia. - Palaeontology 43: 729-763.

Jessen, H. 1993. Weitere Fischreste aus dem Oberen Plattenkalk der Bergisch Gladbach-Paffrather Mulde (Oberdevon, Rheinisches Schiefergebirge). - Palaeontographica A 143: 159-187.

Johnson, J. G. 1960. Geology of the Northern Simpson Park Range, Eureka County, Nevada. Master thesis, University of California, Los Angeles.

Johnson, J. G. 1977. Lower and Middle Devonian faunal intervals in central Nevada based on brachiopods. In Murphy, M. A., Berry, W. B. N. \& Sandberg, C. A. (eds). Western North America: Devonian. University of California, Riverside Campus Museum Contribution 4: 16-32.

Johnson, J. G. 1978. Devonian, Givetian age brachiopods and biostratigraphy. - Geologica et Palaeontologica 12: 117-150.

Johnson, J. G. 1990. Lower and Middle Devonian brachiopod-dominated communities of Nevada, and their position in a biofaciesprovince-realm model. - Journal of Paleontology 64: 902-941.
Johnson, J. G., Sandberg, C. A. \& Poole, F. G. 1988. Early and Middle Devonian paleogeography of United States and their biostratigraphic responses. In McMillan, N. J., Embry, A. F. \& Glass, D. J. (eds). Devonian of the World. Volume I, Regional Synthesis. Canadian Society of Petroleum Geologists, Calgary: pp. 161-182.

Jux, U. 1963. Sedimentologische und biostratinomische Beobachtungen im Oberen Plattenkalk von Bergisch-Gladbach (Devon, Rheinisches Schiefergebirge). - Neues Jahrbuch für Geologie und Paläontologie, Monatshefte 1963 (6): 308-319.

Kuršs, V. 1992. Depositional environment and burial conditions of fish remains in the Baltic Middle Devonian. In Mark-Kurik, E. (ed.). Fossil Fishes as Living Animals. - Academia 1: 251-260.

Lelièvre, H. 2004. Les sites du Dévonien terminal, la caractérisation de leur milieu de dépôt au moyen de l'analyse de similitude de leurs ichthyofaunas. Part 3 of unpublished Habilitation, Lille Université: pp. 137-259.

Lukševičs, E. 2001. Bothriolepid antiarchs (Vertebrata, Placodermi) from the Devonian of the north-western part of the East European Platform. - Geodiversitas 23 (4): 489-609.

McKee, E. H. 1996. Cenozoic magmatism and mineralization in Nevada. In Coyner, A. R. \& Fahey, P. L. (eds). Geology and Ore Deposits of the American Cordillera. Geological Society of Nevada Symposium Proceedings, Reno/Sparks, Nevada, April 1995: pp. 581-588.

Murphy, M. A. 1977. Middle Devonian rocks of central Nevada. In Murphy, M. A., Berry, W. B. N. \& Sandberg, C. A. (eds). Western North America: Devonian. - University of California, Riverside Campus Museum Contribution 4: 190-199.

Murphy, M. A., Morgan, T. G. \& Dineley, D. L. 1976. Astrolepis sp. from the Upper Devonian of Central Nevada. - Journal of Paleontology 50: 467-471.

Reed, J. W. 1979. The Devonian Fish Fauna of Red Hill, Nevada. Unpublished Ph.D. thesis, University of California, Berkeley, California.

Reed, J. W. 1985. Devonian dipnoans from Red Hill, Nevada. - Journal of Paleontology 59: 1181-1193.

Reed, J.W. 1986. The acanthodian genera Machaeracanthus and Persacanthus from the Devonian of Red Hill, Nevada. - Geobios 19 (4): 409-419.

Reed, J. W. 1992. The actinopterygian Cheirolepis from the Devonian of Red Hill, Nevada, and its implications for acanthodian-actinopterygian relationships. In Mark-Kurik, E. (ed.). Fossil Fishes as Living Animals. - Academia 1: 243-249.

Ressel, M. W. 2005. Igneous geology of the Carlin Trend, Nevada: the importance of Eocene magmatism in gold mineralization. Unpublished Ph.D. thesis, University of Nevada, Reno.

Rigby, J. K. \& Harris, D. A. 1979. A new Silurian sponge fauna from northern British Columbia, Canada. - Journal of Paleontology 53: 963-980.

Rigby, J. K. \& Mehl, D. 1994. Middle Devonian Sponges from the Northern Simpson Park Range, Nevada. - Brigham Young University Geological Studies 40: 111-153.

Rohon, J. V. 1900. Die devonischen Fische von Timan in Russland. Sitzungsberichte der Königlich Böhmischen Gesellschaft der Wissenschaften, Mathematisch-naturwissenschaftliche Classe 1899 (8): $1-77$.

Schultze, H.-P. 1969. Griphognathus Gross, ein langschnauziger Dipnoer aus dem Oberdevon von Bergisch-Gladbach (Rheinisches Schiefergebirge) und von Lettland. - Geologica et Palaeontologica 3: 21-79.

Schultze, H.-P. 1999. The Fossil Record of the Intertidal Zone. In Horn, M. H., Martin, K. L. M. \& Chotkowski, M. A. (eds). Intertidal Fishes. Life in Two Worlds. Academic Press, San Diego, London, Boston: pp. 373-392.

Schultze, H.-P. \& Cloutier, R. 1996. Comparison of the Escuminac Formation ichthyofauna with other late Givetian/early Frasnian ichthyofaunas. In Schultze, H.-P. \& Cloutier, R. (eds). Devonian Fishes and Plants of Miguasha, Quebec, Canada. Verlag Dr. F. Pfeil, München: pp. $348-368$ 
Seilacher, A. 1970. Begriff und Bedeutung der Fossil-Lagerstätten. Neues Jahrbuch für Geologie und Paläontolologie, Monatshefte 1970: 34-39.

Sharpe, D. 1856. Descriptions of Palaeozoic Mollusca from South Africa. - Transactions of the Geological Society London (2) 7: 206-215.

Tingley, J. V. \& LaPointe, D. D. 1997. Metals. - Nevada Bureau of Mines and Geology, Special Publication MI-1997 (The Nevada Mineral Industry 1997): 10-26.

Upeniece, I. 2002. Asterolepis (Placodermi): Biogeography, Biostratigraphy and Habitat. - 5th Baltic Stratigraphy Conference "Basin Stratigraphy - Modern Methods and Problems", Vilnius 2002: 211-214.

Upeniece, I. \& Upenieks, J. 1992. Young Devonian antiarch (Asterolepis) individuals from the Lode quarry, Latvia. In Mark-Kurik, E. (ed.). Fossil Fishes as Living Animals. - Academia 1: 167-176.
Young, G. 1981. Biogeography of Devonian vertebrates. - Alcheringa 5: 225-243.

Young, G. 1993. Middle Palaeozoic macrovertebrate biostratigraphy of Eastern Gondwana. In Long, J. A. (ed.). Palaeozoic Vertebrate Biostratigraphy and Biogeography. Belhaven Press, London: pp. 208-251.

Young, G. 2003. North Gondwana mid-Palaeozoic connections with Euramerica and Asia: Devonian vertebrate evidence. - Courier Forschungsinstitut Senckenberg 242: 169-185.

Young, G. 2008. Relationships of tristichopterids (osteolepiform lobe-finned fishes) from the Middle-Late Devonian of East Gondwana. - Alcheringa 32: 321-336.

Ziegler, W., Klapper, G. \& Johnson, J. G. 1976. Revision and subdivision of the varcus zone (Conodonts, Middle-?Upper Devonian) in Europe and North America. - Geologica et Palaeontologica 10: 109-140. 